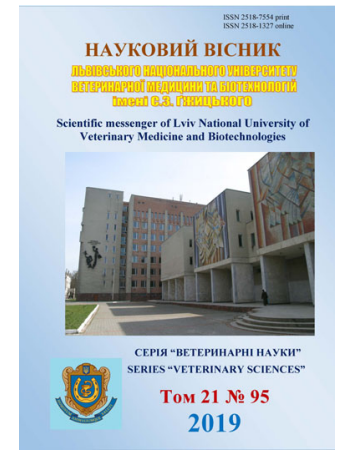

Науковий вісник Дьвівського націонадьного університету ветеринарної медицини та біотехнологій імені С.3. Гжицького.

\author{
Серія: Ветеринарні науки
}

Scientific Messenger of Lviv National University of Veterinary Medicine and Biotechnologies. Series: Veterinary sciences

\title{
Ethiopathogenetic aspects and laboratory diagnostics of viral respiratory-intestinal infections of calves
}

\author{
O.S. Kalinina \\ Stepan Gzhytskyi National University of Veterinary Medicine and Biotechnologies Lviv, Ukraine
}

Article info

Received 11.09.2019

Received in revised form 11.10.2019

Accepted 14.10.2019

Stepan Gzhytskyi National University of Veterinary Medicine and Biotechnologies Lviv, Pekarska Str., 50, Lviv, 79010, Ukraine.

Tel.: +38-096-483-67-86 E-mail:kalininaos@ukr.net

Kalinina, O.S. (2019). Ethiopathogenetic aspects and laboratory diagnostics of viral respiratoryintestinal infections of calves. Scientific Messenger of Lviv National University of Veterinary Medicine and Biotechnologies. Series: Veterinary sciences, 21(95), 80-83. doi: 10.32718/nvlvet9514

The results of a virological and serological study of calves, patients and deaths with symptoms of diarrhea and pneumoenteritis are presented. In the pathological material of 8 calves of 2-8 days of age, sick and deaths with signs of diarrhea, antigens of rotavirus $B(62.5 \%)$ and betacoronavirus $1(100 \%)$ were identified in direct immunofluorescence test, including $62.5 \%$ of animals with associated infection. Serological research of 17 calf convalescents revealed a diagnostic increase in antibodies to rotavirus $B$ $(52.9 \%)$ and betacoronavirus 1 (70.6\%), including $23.5 \%$ of animals with seroconversion to two viruses. In a research of blood sera and colostrum on the first day, 25 cows were found to have antibodies to rotavirus B (20.0\%) and beta-coronavirus 1 (32.0\%) in hemagglutination inhibition test. The relationship between antibody titers in the serum and colostrum of maternal cows and blood serum of newborn calves was established. Antigens of rotaviruses $A$ and $C$, ungulate bocaparvovirus 1 and specific antibodies to them for diarrheal calf disease have not been established. In the pathological material of 11 calves of 15-20 days of age, sick and deaths with signs of pneumoenteritis, antigens of bovine mastadenovirus B (72.7\%) and bovine atadenovirus $D(45.5 \%)$ were identified in direct immunofluorescence test, including $18.2 \%$ of animals are associated with two viruses. In a serological research of 48 calf-convalescents, a diagnostic increase in antibody titers to bovine mastadenovirus $B(66.7 \%)$ and bovine atadenovirus $D(50.0 \%)$ was detected in hemagglutination inhibition test. In a study of colostrum on the first day of 22 cows, antibodies to bovine mastadenovirus $B(27.3 \%)$ and bovine atadenovirus $D(18.2 \%)$ were detected. Antigens of bovine mastadenovirus $A$ and $C$, pestiviruses $A$ and $B$, mammalian orthoreovirus, ungulate bocaparvovirus 1 and specific antibodies to them for pneumoenteritis of calves have not been established. Therefore, in the etiopathogenesis of diarrheal disease of newborn calves, the involvement of rotavirus $B$ and betacoronavirus 1 was established. The presence of colostrum antibodies did not protect calves from rotavirus and coronavirus infections, did not block the secretion of viruses from feces, and correlated with their mire contents. Colostrum antibodies inhibited the body's immunological response to infection. The participation of bovine mastodenovirus and bovine atadenovirus $D$ has been found in the etiopathogenesis of calf pneumoenteritis. These viruses latently infect adult animals as a source of infectious agents for calves. Key
bodies.

Key words: respiratory-intestinal infections, diarrhea, pneumoenteritis, calves, viruses, antigens, anti-

\section{Етіопатогенетичні аспекти та лабораторна діагностика вірусних респіраторно-кишкових інфекцій телят}

\author{
О.С. Калініна
}

Львівський національний університет ветеринарної медиџини та біотехнологій імені С.3. Гжицького, м. Львів, Україна 
Наведено результати вірусологічного й серологічного дослідження телят, хворих $і$ загиблих із симптомами діареї та пневмоентериту. У патологічному матеріалі 8 телят 2-8-денного віку, хворих $і$ загиблих з ознаками діареї, ідентифіковано в РІФ антигени ротавірусу В (62,5\%) і бетакоронавірусу 1 (100\%), в тому числі в 62,5\% тварин встановлено асоиійовану інфекцію. За серологічного дослідження 17 телят-реконвалесцентів виявлено у РЗГА діагностичне зростання титрів антитіл до ротавірусу В (52,9\%) i бетакоронавірусу 1 (70,6\%), у тому числі в 23,5\% тварин встановлено сероконверсію до двох вірусів. При дослідженні сироваток крові та молозива першого дня 25 корів виявлено у РЗГА антитіла до ротавірусу В (20,0\%) і бетакоронавірусу 1 (32,0\%). Встановлено взаємозв 'язок між титрами антитіл у сироватках крові й молозиві корів-матерів і сироватках крові новонароджених телят. Антигенів ротавірусів $A$ i $C$, бокапарвовірусу копитних 1 та специфічних антитіл до них за діарейного захворювання телят не встановлено. У патологічному матеріалі 11 телят 15-20-денного віку, хворих і загиблих з ознаками пневмоентериту, ідентифіковано в РІФ антигени мастаденовірусу ВРХ В (72,7\%) та атаденовірусу ВРХ D (45,5\%), у тому числі у $18,2 \%$ тварин встановлено асоиіацію двох вірусів. За серологічного дослідження 48 телят-реконвалесцентів виявлено у РЗГА діагностичне зростання титрів антитіл до мастаденовірусу ВРX В (66,7\%) та атаденовірусу ВРX D (50,0\%). При дослідженні молозива першого дня 22 корів виявлено антитіла до мастаденовірусу ВРX В (27,3\%) та атаденовірусу ВРX D (18,2\%). Антигенів мастаденовірусів ВРХ А $i$ С, пестівірусів $A$ і $B$, ортореовірусу ссавців, бокапарвовірусу копитних 1 та специфічних антитіл до них за пневмоентериту телят не встановлено. Отже, в етіопатогенезі діарейного захворювання новонароджених телят встановлено участь ротавірусу В $i$ бетакоронавірусу 1. Наявність молозивних антитіл не забезпечувала захист телят від ротавірусної та коронавірусної інфекцій, не блокувала виділення вірусів із калом, корелювала з їхнім вмістом у сироватках крові й молозиві корів-матерів. Молозивні антитіла інгібували імунологічну реакцію організму телят на зараження. В етіопатогенезі пневмоентериту телят встановлено участь мастаденовірусу ВРХ В та атаденовірусу ВРХ D. Ці віруси латентно інфікують дорослих тварин, ияо слугують джерелом збудників інфекції для телят.

Ключові слова: респіраторно-кишкові інфекиії, діарея, пневмоентерит, телята, віруси, антигени, антитіла.

\section{Ветуп}

В інфекційній патології телят у сучасних тваринницьких господарствах важливе місце посідають респіраторно-кишкові захворювання, які мають складну вірусно-бактеріальну етіологічну структуру і виникають на тлі несприятливих санітарно-гігієнічних факторів та неоднорідного імунологічного статусу. Респіраторно-кишкові інфекції телят є основною причиною вимушеного забою і загибелі тварин у постнатальний період, а за поширенням, летальністю і недоотриманням приростів превалюють над іншими патологіями (Gumerov, 2016; Levkivska et al., 2016; Sosnickij et al., 2017; Levkivsky et al., 2018). Ці захворювання спричинюють різноманітні віруси (часто в асоціації з бактеріями, мікоплазмами, хламідіями), що значно ускладнює інфекційний процес та утруднює діагностику і профілактику. Це, зокрема, збудники парагрипу-3 BPX (респіровірус ВРX 3), інфекційного ринотрахеїту ВРX (альфагерпесвірус ВРX 1), вірусної діареї ВРX (пестівіруси А і В), респіраторно-синцитіальної інфекції ВРХ (ортопневмовірус ВРХ), аденовірусної інфекції ВРX (мастаденовіруси ВРX А, В і С, атаденовірус BPX D), ротавірусної інфекції ВРX (ротавіруси А, В і C), коронавірусної інфекції ВРХ (бетакоронавірус 1), парвовірусної інфекції ВРХ (бокапарвовірус копитних 1), реовірусної інфекції ВРХ (ортореовірус ссавців) (Kashko \& Krasochko, 2014; Chebaniuk, 2015; Gumerov, 2016; Prokhoriatova et al., 2017), ентеровірусної інфекції ВРX (ентеровіруси Е і F) (Stetsenko, 2011; Sosnickij et al., 2017).

Дослідження патогенезу респіраторно-кишкових інфекцій телят показує, що роль різних вірусів у розвитку і тяжкості патологічних процесів неоднозначна. Поліетіологічність цих захворювань телят змушує критично підходити до оцінки відносного значення в патології кожного вірусу і зовсім не означає, що всі вони одночасно беруть участь в інфекційному процесі (Gumerov, 2016; Sosnickij et al., 2017). За асоційованих респіраторно-кишкових інфекцій телят часто важко визначити роль того чи іншого патогена, який виділя- ється з патологічного матеріалу хворих тварин. Зазвичай, пусковим механізмом у патогенезі респіраторнокишкових інфекцій телят $є$ віруси, а після їхньої цитодеструктивної дії в патологічний процес вступають бактерії. Хоч і прийнято вважати, що бактеріальні інфекції є вторинними, проте від них багато в чому залежить тяжкість перебігу і наслідок хвороби. В кінцевому підсумку тварина гине від секундарної мікрофлори, яка нерідко буває умовно-патогенною (Chebaniuk, 2015; Gumerov, 2016; Sosnickij et al., 2017). За асоційованих респіраторно-кишкових інфекцій не завжди вдається ізолювати віруси, і часто їхня первинна етіологічна роль залишається нез'ясованою внаслідок постановки діагнозу на бактеріальні хвороби (Stetsenko, 2011).

Вирішальне значення в постановці діагнозу має лабораторна діагностика у зв'язку з поліетіологічністю респіраторно-кишкових інфекцій телят та подібністю клініко-епізоотологічних даних і патологоанатомічних змін. Вибір методу лабораторної діагностики визначається в кожному конкретному випадку залежно від характеру захворювання, властивостей підозрюваного збудника і можливостей лабораторії. Актуальним завданням сучасної вірусології $\epsilon$ розробка i впровадження у виробництво наборів діагностикумів для постановки серологічних реакцій, які мають широке застосування в діагностичній практиці (Sjurin et al., 1986). Своєчасна ідентифікація збудників вірусної етіології дає змогу встановити першопричину хвороби, вибрати стратегію лікувально-профілактичних заходів у кожному конкретному випадку і таким чином зменшити втрати молодняку (Sosnickij et al., 2017; Prokhoriatova et al., 2017).

Метою роботи було встановити етіологію інфекційного захворювання телят із симптомами діареї та пневмоентериту у двох господарствах західного регіону України та оцінити інформативність методів лабораторної діагностики. Відповідно до мети були поставлені такі завдання: 1) провести клінікоепізоотологічне обстеження тварин та відібрати відповідний матеріал для вірусологічного і серологічно- 
го досліджень; 2) дослідити патологічний матеріал від хворих і загиблих телят на наявність вірусних антигенів; 3) дослідити сироватки крові телятреконвалесцентів, корів-матерів і проби молозива на наявність специфічних антитіл.

\section{Матеріал і методи досліджень}

Для лабораторної діагностики брали такий досліджуваний матеріал: 1) від 8 телят віком 2-8 діб, хворих і загиблих $з$ ознаками діареї, за життя - проби калу і сироватки крові, взяті на початку хвороби; посмертно - слизова оболонка тонкого кишечнику; 2) від 17 телят до 12-денного віку, що хворіли з ознаками діареї, - проби калу, взяті на початку хвороби; парні сироватки крові, взяті на початку і наприкінці хвороби $з$ інтервалом 10 діб; 3) від 12 телят 15-20денного віку, хворих і загиблих з ознаками пневмоентериту, за життя - змиви 3 носової порожнини i кон'юнктиви, проби калу, сироватки крові, взяті на початку хвороби; посмертно - слизові оболонки носа, трахеї, тонкого кишечнику, легені, лімфатичні вузли (середостінні, брижові); 4) від 48 телят до 30-денного віку, що хворіли з ознаками пневмоентериту, - змиви 3 носової порожнини і кон'юнктиви, проби калу, парні сироватки крові, взяті на початку і наприкінці хвороби з інтервалом 10-14 діб; 5) від 25 корів-матерів сироватки крові; 6) від 47 корів-матерів - молозиво першого дня.

Вірусні антигени виявляли в РІФ, специфічні антитіла - у РЗГА і РНГА. Серологічні реакції ставили за загальноприйнятими методиками (Sjurin et al., 1986) $з$ використанням діагностичних наборів виробництва НВО “НАРВАК” (РФ).

\section{Результати та їх обговорення}

У патологічному матеріалі 8 новонароджених телят, загиблих із симптомами діареї, ідентифіковано в РІФ антигени ротавірусу В (5 тварин - 62,5\%) і бетакоронавірусу 1 (8 тварин - 100\%), у тому числі в 5 тварин (62,5\%) встановлено асоційовану інфекцію. Дифузне і гранулярне світіння вірусних антигенів на 3-4 плюси спостерігали в цитоплазмі епітеліальних клітин слизової оболонки тонкого кишечнику.

При дослідженні сироваток крові загиблих телят, які були взяті на початку захворювання, виявлено невисокі титри молозивних антитіл до ротавірусу В у 2 тварин (25,0\%) (середній титр $\left.3,5 \pm 0,71 \log _{2}\right)$ і до бетакоронавірусу 1 - у 3 тварин (37,5\%) (середній титр $\left.3,7 \pm 0,76 \log _{2}\right)$. Антигенів ротавірусів А і C, бокапарвовірусу копитних 1 та специфічних антитіл до них не встановлено.

За серологічного дослідження у РЗГА 17 телят до 12-денного віку, які перехворіли із симптомами діареї, виявлено на початку хвороби в 3 телят $(17,6 \%)$ антитіла молозивного походження до ротавірусу В (середній титр 4,3 $\left.\pm 0,76 \log _{2}\right)$ і у 5 телят $(29,4 \%)$ - до бетакоронавірусу 1 (середній титр 4,4 $\pm 0,28 \log _{2}$ ). Наявність молозивних антитіл не забезпечувала за- хист від інфекції, не блокувала виділення вірусу 3 калом та інгібувала імунологічну реакцію організму на зараження.

На стадії видужання в сироватках крові всіх 17 телят виявлено специфічні антитіла, а саме: у 9 тварин $(52,9 \%)$ - до ротавірусу В (середній титр 6,4 \pm $\left.0,19 \log _{2}\right)$ і 12 тварин $(70,6 \%)$ - до бетакоронавірусу 1 (середній титр $6,8 \pm 0,22 \log _{2}$ ), у тому числі в 4 тварин $(23,5 \%)$ встановлено сероконверсію до двох вірусів. Діагностичне (4-8-разове) зростання титру антитіл спостерігали у тварин серонегативних і 3 невисоким рівнем материнських антитіл $\left(4 \log _{2}\right)$. У телят із титром антитіл на початку хвороби $5 \log _{2}$ кількість антитіл зросла лише в 2 рази, а у тварин із титром антитіл $6 \log _{2}$ не спостерігалася сероконверсія в період реконвалесценції.

За серологічного дослідження 25 корів-матерів у сироватках крові та молозиві першого дня у 5 тварин (20,0\%) виявлено антитіла до ротавірусу В (середні титри відповідно 5,8 $\pm 0,47 \log _{2}$ i 7,2 $\left.\pm 0,41 \log _{2}\right)$ і у 8 тварин (32,0\%) - до бетакоронавірусу 1 (середні титри відповідно 6,5 $\pm 0,20 \log _{2}$ і 7,6 $\pm 0,20 \log _{2}$ ). Встановлено взаємозв'язок між титрами антитіл у сироватках крові й молозиві корів-матерів і сироватках крові новонароджених телят.

Не виявлено істотних відмінностей в інтенсивності прояву клінічних ознак і тяжкості перебігу хвороби в серопозитивних та серонегативних тварин, що пов'язано з патогенетичними особливостями вогнищевих вірусних інфекцій. Як відомо, за ротавірусної та коронавірусної інфекцій ВРХ імунітет забезпечується не гуморальними антитілами, а такими, що містяться в просвіті кишечнику. Це можуть бути молозивні антитіла до їхньої адсорбції в кров або секреторні антитіла класу $\operatorname{IgA}$, що виробляються лімфоїдними клітинами слизової оболонки тонкого кишечнику на четверту добу після народження. Антитіла, локалізовані в просвіті кишечнику, блокують вірус у місці його репродукції, чим попереджається його адсорбція на чутливих клітинах і подальше інфікування їх.

Антитіл до ротавірусів А і C та бокапарвовірусу копитних 1 у сироватках крові телят, корів-матерів $\mathrm{i}$ молозиві на встановлено.

У патологічному матеріалі 11 телят 15-20-денного віку, загиблих з ознаками пневмоентериту, ідентифіковано в РІФ аденовірусні антигени. 3 них у 8 тварин $(72,7 \%)$ виявлено антиген мастаденовірусу ВРХ В, а в 5 тварин (45,5\%) - антиген атаденовірусу BPX D, у тому числі у 2 тварин $(18,2 \%)$ встановлено асоціацію двох вірусів. Гранулярне світіння вірусних антигенів на 3-4 плюси спостерігали найчастіше в ядрах епітеліальних клітин слизової оболонки носа, кон'юнктиви, трахеї, тонкого кишечнику та легень, рідше - у клітинах середостінних і брижових лімфатичних вузлів.

У пробах патологічного матеріалу (кал, змиви 3 носа і кон'юнктиви) всіх 48 телят, хворих з ознаками пневмоентериту, ідентифіковано аденовірусні антигени. У 32 телят $(66,7 \%)$ ідентифіковано антиген мастаденовірусу ВРХ В, у 24 телят (50,0\%) - антиген ата- 
деновірусу BPX D, в тому числі у 8 тварин $(16,7 \%)$ встановлено асоціацію обох вірусів.

За серологічного дослідження 48 телят до 30денного віку, що перехворіли з ознаками пневмоентериту, у сироватках крові на початку хвороби, виявлено у РЗГА невисокі титри антитіл до мастаденовірусу ВРX В у 12 тварин (25,0\%) (середній титр 3,6 $\pm 0,16$ $\left.\log _{2}\right)$ та у 7 тварин $(14,6 \%)$ - антитіла до атаденовірусу BPX D (середній титр 3,4 $\pm 0,23 \log _{2}$ ). Ці антитіла тварини набули з молозивом корів-матерів. На стадії видужання встановлено діагностичне зростання титру антитіл до мастаденовірусу ВРХ В у 32 тварин $(66,7 \%)$ (середній титр 6,7 $\left.\pm 0,16 \log _{2}\right)$ та у 24 тварин $(50,0 \%)$ - до атаденовірусу ВРX D (середній титр $\left.6,9 \pm 0,21 \log _{2}\right)$. Варто зазначити, що у 8 тварин $(16,7 \%)$ встановлено сероконверсію до двох вірусів.

Результати вірусологічного і серологічного дослідження 48 телят до 30-денного віку, що перехворіли 3 ознаками пневмоентериту, повністю збігалися.

При дослідженні молозива першого дня 22 корів у 6 тварин (27,3\%) виявлено антитіла до мастаденовірусу ВРX В (середній титр 5,0 $\left.\pm 0,28 \log _{2}\right)$ і у 4 тварин $(18,2 \%)$ - антитіла до атаденовірусу BРX D (середній титр $\left.4,8 \pm 0,39 \log _{2}\right)$. Це свідчить про циркуляцію збудників у господарстві та латентне інфікування дорослих тварин, які слугують джерелом збудників інфекції для новонародженого потомства.

Антигенів мастаденовірусів ВРX А і С, ортореовірусу ссавців, пестівірусів А і В, бокапарвовірусу копитних 1 та ентеровірусів E і F у патологічному матеріалі хворих і загиблих з ознаками пневмоентериту телят та специфічних антитіл до них не виявлено.

\section{Висновки}

В етіопатогенезі діарейного захворювання новонароджених телят встановлено участь ротавірусу В і бетакоронавірусу 1 . Наявність молозивних антитіл не забезпечувала захист телят від ротавірусної та коронавірусної інфекцій, не блокувала виділення вірусів із калом, корелювала з їхнім вмістом у сироватках крові й молозиві корів-матерів. Молозивні антитіла інгібували імунологічну реакцію організму телят на зараження. В етіопатогенезі пневмоентериту телят встановлено участь мастаденовірусу ВРХ В та атаденовірусу BPX D. Ці віруси латентно інфікують дорослих тварин, що слугують джерелом збудників інфекції для телят.

Перспективи подальших досліджень. Треба проводити систематичний серологічний моніторинг поголів'я ВРХ різновікових груп на наявність специфічних антитіл до вірусів - збудників респіраторнокишкових інфекцій. Це дасть змогу контролювати циркуляцію вірусів у різних регіонах і розробляти ефективні лікувально-профілактичні заходи.

\section{References}

Chebaniuk, I.V. (2015). Virusno-bakterialni pnevmoenteryty velykoi rohatoi khudoby. Veterynarna medytsyna, 101, 136-138. http://jvm.kharkov.ua/sbornik/101/4_38.pdf (in Ukrainian).

Gumerov, V.G. (2016). Diagnostika i specificheskaja profilaktika respiratornyh i zheludochno-kishechnyh infekcij krupnogo rogatogo skota: avtoref. diss. ... dokt. vet. nauk. Kazan' (in Russian).

Kashko, L.S., \& Krasochko, P.P. (2014). Serologicheskij monitoring krupnogo rogatogo skota $\mathrm{V}$ otnoshenii viru-sov-vozbuditelej pnevmojenteritov teljat. Dostizhenija nauki i tehniki APK, 28(11), 66-68. http://www.agroapk.ru/44-archive/11-2014/566-201411-19-ru (in Russian).

Levkivska, N., Gutyj, B., \& Levkivskyj, D. (2016). Comparative effectiveness therapeutic and prophylactic preparations when applying 3\% of ethanol-water emulsion of propolis and antibiotics for catarrhal pneumonia in calves. Scientific Messenger LNUVMBT named after S.Z. Gzhytskyj, 18, 2(66), 116-121. doi:10.15421/nvlvet6624.

Levkivsky, D.M., Levkivska, N.D., Gutyj, B.V., \& Leno, M.I. (2018). Analysis of treatment and preventive measures for infectious diseases of calves, Agricultural Enterprise "Volovikov" Ltd, Goshansky district, Rivne region. Scientific Messenger of Lviv National University of Veterinary Medicine and Biotechnologies, 20(83), 93-96. doi: 10.15421/nvlvet8318.

Prokhoriatova, O.V., Kornieikov, O.M., Kolchyk, O.V., \& Isakov, M.M. (2017). Vyznachennia osnovnykh prychyn poshy-rennia infektsiinykh pnevmoenterytiv velykoi rohatoi khudoby v suchasnykh umovakh. Veterynarna medytsyna, 103, 209-213. http://jvm.kharkov.ua/sbornik/103/3_47.pdf (in Ukrainian).

Sjurin, V.N., Belousova, R.V., Solov'ev, B.V., \& Fomina, N.V. (1986). Metody laboratornoj diagnostiki virusnyh boleznej zhivotnyh: Spravochnik. Moskva: Agropromizdat (in Russian).

Sosnickij, A.I., Masjuk, D.N., Koljada, S.G., Kokarev, A.V., \& Shatalov, S.A. (2017). Jetiopatogenez, diagnostika i immunoprofilaktika pnevmojenteritov u teljat. Kormi i fakti, 3(79), 8-10 (in Russian).

Stetsenko, V.I. (2011). Shvydka ta nadiina dyferentsiina diahnostyka - holovna umova efektyvnosti likuvannia ta spetsyfichnoi profilaktyky asotsiiovanykh virusnobakterialnykh pnevmoenterytiv teliat. Veterynarna medytsyna, 95, 429. http://irbis-nbuv.gov.ua/cgibin/opac/search.exe?I21DBN=LINK\&P21DBN=UJRN $\& Z 21 \mathrm{ID}=\& \mathrm{~S} 21 \mathrm{REF}=10 \& \mathrm{~S} 21 \mathrm{CNR}=20 \& \mathrm{~S} 21 \mathrm{STN}=1 \& \mathrm{~S}$ 21FMT=ASP_meta\&C21COM=S\&2_S21P03=FILA= \&2_S21STR=vetmed_2011_95_196 (in Ukrainian). 